\title{
The Media Consumption Patterns of the Arab Spring Revolutions: A Field Study for the students' Perceptions in the faculty of Journalism and Press at Al-yarmouk University
}

\author{
Tahseen Mohammad Anis Sharadga ${ }^{1}$ \\ ${ }^{1}$ Assistant Professor Al-Zarqa'a University, Faculty of, Journalism ,Jordan \\ Correspondence: Tahseen Mohammad Anis Sharadga, Assistant Professor Al-Zarqa'a University, Faculty of, Journalism, \\ Jordan.
}

Received: June 22, 2016 Accepted: October 27, 2016 Online Published: October 28, 2016

doi:10.11114/smc.v4i2.1951 URL: http://dx.doi.org/10.11114/smc.v4i2.1951

\begin{abstract}
The study aimed to identify the media consumption patterns of the Arab Spring revolutions from the viewpoint of Yarmouk University students. In addition to detect whether there is a statistically significant differences at the level of significance $(\alpha=0.05)$ with respect to the views of respondents regarding employing the study dimensions related to political, military and human dimension due to the variables of the study (sex, educational qualification). The study sample consisted of Yarmouk University students (200) students. The descriptive analytical method was used, through which the following results were concluded:

1. Identifying the media consumption patterns on the Arab Spring.

2. No statistically significant differences at the level of significance $(\alpha=0.05)$ with respect to the views of respondents about media consumption patterns of the Arab Spring due to the variable of sex.

3. There are no statistically significant differences at the level of significance $(\alpha=0.05)$ with respect to the views of respondents about media consumption patterns around of Arab Spring due to the educational qualification variable.

Based on the results of the theoretical and empirical study, the researcher suggests the following:

Identify the mechanisms through which media networks broadcast the political propaganda related to the political, military and human dimensions, and the procedures used to do so. Also studying the methods by which the propaganda messages are being broadcast and analyzed, and employing them for the public interest. In addition to analyzing the means by which the propaganda messages are sent whether they are political or other, with focusing on the procedures used to publish them. Finally, identifying the media mechanisms to dedicate the phenomenon of political propaganda based on honesty and objectivity in the media work.
\end{abstract}

Keywords: media - the Arab spring

"This research is funded by the Deanship of Research and Graduate Studies in Zarqa University /Jordan".

\section{Introduction}

Arab Spring played a key role in the destabilization of the pillars of the Arab media during the last decade, and this more clearly manifested in countries where the political movement and social tension factors cropped up since the beginning of the decade, and possibly Tunisia, Egypt, Syria and Yemen are the most prominent of those countries. The relative Democratic margin conditions and freedoms available in these countries allowed the stimulate the private press and TV channels, and employed what has become known as new media tools to rebel against the official media constants, and the liberalization of large segments of the public from its power. It is not exaggeration in this context to say that the synergies and unique cross-fertilization that has developed between traditional media and between the new media that the official Arab media were unable to contain it, has played the most important role in creating the generations of the Arab Spring revolution and the development of the political and societal beliefs, assuring that if the political and social oppression and tyranny of the ruling regimes, are the detonator of the revolutions of the peoples, the free and independent media is the one which will create a precipitate and its completion(Mirghani.2011). 
The follower of the dialectic of the revolution and the media notices that cross-correlation between the elements of the revolution and the state of the media in specific spatial and temporal conditions. Revolutions as a direct embodiment of the will of the people can not be imagined in the absence of communicative and cognitive system able to mobilize the forces of the revolution and the organizing the in the direction of the target, and in the circumstances in which the ruling regimes dominate the media machine, the rebels must seek to bring about gaps in the current information system to occupy influential spaces between the flanks, or work on the production of new communicative and cognitive alternatives to embody visions of the revolution and its requirements (Salha, 2013). Evidence of the Arab Spring confirm that the forces of change in the Arab reality has passed -and stills- through both of these roads together, which explains the prominent position of the slogans of press and media freedom within the demands of the revolutionary and reformist movement across the Arab world, with a deep interest of the political forces and movements to invest the information and communication technology revolution on a global level (Bouhnah, 2012).

The media have an active role in shaping the context of the political reform in the various communities; where it reflects the nature of the relationship between state and society, and between the elite and the masses (Almana'ai, 2014). The contribution and role of the media in the political and democratic reform depends on the form and the function of these means in the community and the size of freedoms, and the plurality of opinions and trends within these institutions, along with the nature of the cultural, social and political factors inherent in the society; the nature and the role of the media in strengthening democracy, promoting political participation values and making political decision, is associated with the philosophy of the political system under which they operate, and the degree of freedom enjoyed by the social construction inside (Mathieu, 2011).

Based on the foregoing, the follower of what is happening in the Arab region and of Western studies finds that some Western studies have addressed the issue of the abuse of satellite TV with the events of recent Arab countries, including a study conducted by "Komtrax Solutions" a Lebanese institution specializing in media monitoring, about the abuse of the "Al Arabya" and "Aljazeera "and" BBC "with the events in the month of August 2009 in a number of countries, which dominated the news bulletins of these stations (Abdul Ghani, 2011). The study, titled "the battlefields of the Middle East in 2009," has monitored the media coverage in the sixth pm GMT bulletins in the three stations. According to this study, "Iraq's share of media coverage of the countries in the three stations, amounted to $13 \%$, followed by the news of Palestine according to "Alhayah" of London, with Iran entered by $8 \%$ in the media coverage, due to the continuation of its crisis after the presidential election. The study found that the Iraqi events acquiring of the bulk of the media coverage was due to the attention given by "BBC "and" Aljazeera "in this matter, especially the bombings in Iraq in August 19, but " Alrabya "have shown, according to the study," more attention to the Iranian subject that dominated the beginnings of their news bulletins often ". The study also referred that the fighting in Yemen began to appear in the media in August, with nearly $5 \%$ of coverage, while the war in Afghanistan 6\%. The "BBC" was the most of the three stations in handling the Yemeni subject by $6 \%$, followed by "Al Jazeera" and "Alrabya" in equal proportions amounted to $4 \%$. The Afghanistan war coverage decreased by "Alrabya", while it was about $8 \%$ of the entire coverage of "BBC" and " Al Jazeera " (Gholioun, 2015).

In regards to the Iranian issue, the three stations have agreed during August on the fact that the Iranian crisis is unfinished. In terms of the overall situation in Iraq, the study noted that "the BBC" focused on the importance of the role of the United States, Britain and the impact of the withdrawal of their troops on the Iraqi situation, while "Alarabya", has focused on the tension in Syrian-Iraqi relations." While "Aljazeera" highlighted the mediations and foreign interventions in Iraq, especially the neighboring countries which have an important role in deciding what is going on in the country, but this also did not prevent "Aljazeera" of referring to the" setback "and" test "in which the security forces failed in Iraq(Abdulrahman Elsamni, 2016).

Arab Spring events dramatically developed day by day in many countries at the same time. From this point it is naturally for media channels to compete in covering "HOT EVENTS" with its commitment to its political line and its strategy towards countries and regimes (Dulaimi, 2011). Appointing a circumstance repeated during the events which is the absence of the satellite and its sudden suspend to broadcast many times by intended disturbance operations from (unknown) parties as said, but of course it is parties follow the governing regimes. Accordingly are the current channels not entitled or not ready to face the corrupting and disturbance operations? We saw the disturbance operations in the events in Tunisia, Egypt and Syria and suspending broadcasting for moments or for long periods in Aljazzera, Al-Arabiya and Alhurra channels then moving to other frequencies and sometimes we witnessed full suspend from the satellite like what happened to Aljazeera channel and its suspend from the Nile sat at the time of " 25 January" events (Ka'isis, 2012).

It is known that as much as channels abilities increase and develop, as much as the abilities of the disruptive parties develop in affecting broadcasting. This disturbance confirms the role of the two channels Aljazeera and Al-Arabiya in affecting the Arabic public opinion and in directing people and positions. This is for sure something the current regimes 
do not like specially when they woke up one day to find thing turned against them (Ka'isis, 2012).

YouTube videos which were uploaded by revolution young men took part in this role and in helping the satellite channels to carry on the events moment by moment because these channels gave the revolution young men limited space like in Aljazeera named 'the journalist citizen' and in Al-Arabia 'I see' by this way they got the ability to cover most of the events which their reporters couldn't cover. In addition to establishing 'observation' webs in all Arabic countries on Facebook posting news of protests and demonstrations in all cities and all other details of injuries and arrests from the events source '(The Arabic Network for the Study of Democracy, 2013).

Aljazeera chose the slogan 'the opinion and the other opinion' which explains the appearance of famous media men in attractive conversational programs which have wide range of Arabic audience appeared from prima facie as not identical ideologically. This type is available in most of the western serious media channels (Al-Assaf, 2012). In BBC for example, simply we can find lift journalist and others right. The explanation and excuse to it is that the world of opinions is different, contradicting, opposing, various, fluctuated and developed in which there is no way to talk about impartialness or objectivity. It has big side of subjectivity; human view of life is different and the type of his political, economical, social, cultural, spiritual and religious programs are different, various and even contradicted. As a result what is requested is to avail the chance to this variety and big mix of opinions and contradictions to express himself in the same media (Ala'alm, 2013).

This is behind accusing Aljazeera of a certain ideological color. It is often accused of having Islamic or Arab nationalist motivations because of the nature of its guests and success in the delivery of the message it wants to deliver; and sometimes of treason and hiding the real objectives as happened recently (Lauren Williams, 2016). But the interpretation of that brings us back to the fact that Arab societies themselves, which are currently dominated by Islamic movements with the presence of the Arab nationalist currents which are also dependent on the political legacy of the glory that has been witnessed in the fifties and sixties of the last century (Besol, 2014). These letters find an echo in public opinion now because of economic and cultural intertwined political conditions (Gholioun, 2015). And if an opportunity has been allowed to streams of liberalism or Marxism, they would not find a great success because the Arab public opinion at the present time is not excited to them and the ideological landscape may evolve and change in the coming decades.

So, the Arab and international media have focused at the beginning of the year 2011 on the Arab Spring and its impact on the Arab region and the world, in terms of both what they are, which started since 2012 and inclusive development. Thus, the search in the patterns of media consumption on the Arab spring mechanisms is justified in light of what is happening on the Arab and international arena of events relate to the policies of states, in addition to identifying these mechanisms means, which is the prime motivator of the events that happens in the Middle East through employing political, military and humanitarian dimensions.

\section{Problem of the Study}

The actual coverage of the big Arab channels, which was and is continuous through Al Jazeera and Alarabya, is considered to be important in the activation of the political and social mobility in the Arab Spring countries. A quick look at satellite televisions and other media including social networking sites is needed; the researcher in the Arab Association of Communication Sciences Mai Al-Abdullah has confirmed that Alarabya news channel practiced a liberal line in dealing with the events, and this is clear in its news coverage in Tunisia, Egypt, Syria and Libya and Yemen. Alarabya depends on the professionalism of news work without entering into the battle; it keeps itself in the same distance of all the conflicting parties and gives the opportunity to all parties to express their views and attitudes. It does not make the news, but kept pace with the event up close without leaving the details, allowing it and their offices to continue within states without the closure of its offices, and this applies to the spring of Syria Revolution by talking to spokesmen of the regime or the opponents activists from inside Syria, relying on the reporter who is not connected the event and its impact on the public street; it also depends on foreign and Syrian private agencies and eyewitnesses from the inside if there is a possibility. On the other hand "American Foreign Policy" Magazine has deemed that many of the predictions of Arab people Al-Jazeera television will help in the outbreak of the popular uprising in the Middle East has become a reality. The magazine confirmed that Al-Jazeera television has played a key role in the popular revolution in Tunisia, which sparked began in the city of Sidi Bouzid, and ended up tidal wave threatening to overthrow the Egyptian regime. The magazine also noted that due to the enormous influence of Al-Jazeera in the Arab Street, dictatorships in the region have become threatened by waves of protests that may include Algeria, Jordan, Yemen, Bahrain, at the same time wondering about the possibility of the threat of the Al-Jazeera to Saudi Arabia. Here it is true to say that Al Jazeera had been adopted since the start of the Arab revolutions the coverage of the street and keep up with the Rebel audience as if they are Lenin's party channel, which says that the commitment with the people is the foundation, where the popular street is we are the party communist will be, " Al-Jazeera has become with the Arab street during its coverage, it 
was with the Arab oppositions led by the street, prompting many Arab repressive countries to close its offices, but on the other hand they gained satisfaction of the fiery street. All this has pushed the researcher to reflect on how the media consumed the Arab spring revolutions trying to diagnose the current societal context of the Arab countries to answer the main study question:

What are the media consumption patterns of the Arab spring revolutions from the viewpoints of students of the faculty of Press at Alyarmouk University?

\section{The Study Questions}

The current study will try to answer the following questions:

1. What are the media consumptions patterns of the Arab Spring revolutions regarding the political dimension?

2. What are the media consumptions patterns of the Arab Spring revolutions regarding the military dimension?

3. What are the media consumptions patterns of the Arab Spring revolutions regarding the human dimension?

4. Is there any statistically significant differences at $(\alpha=0.05)$ in relation to the sample perceptions towards the media consumptions patterns of the Arab Spring revolutions due to the sample variables (Scientific qualification, gender)?

\subsection{The Study Goals}

1. Identifying the consumption media patterns of the Arab Spring revolutions in relation to the political dimension.

2. Identifying the consumption media patterns of the Arab Spring revolutions in relation to the military dimension.

3. Identifying the consumption media patterns of the Arab Spring revolutions in relation to the human dimension.

4. Identifying whether there is any statistically significant differences at $(\alpha=0.05)$ in relation to the sample perceptions towards the media consumptions patterns of the Arab Spring revolutions due to the sample variables (Scientific qualification, gender)?

\subsection{Significance of the Study}

The significance of this study lies in the important role of media on the Arab Spring revolutions, and how it affects the people lives in the Arab countries:

1. Clarifying the important role of media in the Arab Spring revolutions.

2. Monitoring the reality of the media, in connection with the political, military and humanitarian aspects of these revolutions.

3. Shedding the light on the media that affected the Arab Spring revolutions negatively.

4. It may be the base from which journalists can reveal more cognitive facts related to the phenomenon of the Arab Spring.

\subsection{Delimitations of the Study}

Study tools have been applied on the students of the School of Journalism and Media at the University of Yarmouk in Jordan in 2015. It was confined to know the impact of the media on the revolutions of the Arab Spring, and to identify the key dimensions through the field study.

\subsection{Terms of the Study}

\subsubsection{Arab Spring}

Is a series of Arab political revolutions that swept many countries in the Middle East against the dictatorship of the Arab governments, from Tunisia and Egypt, and Libya and other Arab countries most notably Syria, which is still occupying a space in the international media.

\subsubsection{Pattern}

Spooner identifies it as an unexpected behavior in a given situation, taking into account the social norms prevailing in the Community and the aspirations and requirements and social organization (2000, Spooner). The researcher puts it as "the tasks of the media in presenting facts and messages, opinions, and its impact on the Arab Spring, all the way to the major goals of freedom and human dignity. 


\subsubsection{Media}

Is the collection, storage, processing and dissemination of news and data, photos, facts and messages, opinions and comments required to see the ongoing accidents and cover events impartially and accuracy and credibility, so they are well-respected from public (Gavrilos, 2002).

\subsection{Field Study}

\subsubsection{Methodology of the Study}

The researcher followed in this study the descriptive analytical approach, where he monitored the patterns of media consumption of the Arab Spring, from the standpoint of Yarmouk University students in the Hashemite Kingdom of Jordan. Data were collected, and then analyzed in order to reach certain results help to explain the phenomenon and to answer questions about the study; through a questionnaire study addresses the main dimensions.

\subsubsection{Population and the Sample of the Study}

The study population consisted of all Yarmouk University students, next the researcher chose a deliberated- sample composed of (200) students from Yarmouk University students. After determining the required sample size, the sample was chosen taking into account their distribution ratios in the original population due to the variables of the educational qualification and gender. The following table shows the sample's distribution according to the variables of educational qualification and gender

Table 1. The sample's distribution according to the variables of educational qualification and gender

\begin{tabular}{rrrr}
\hline Total & & Gender & Educational \\
& Females & Males & Qualification \\
126 & 49 & 77 & Bachelor Degree \\
74 & 32 & 42 & Graduate \\
$\mathbf{2 0 0}$ & 81 & 119 & Total \\
\hline
\end{tabular}

It is clear from table (1) that the study sample was distributed according to gender to (119) male students representing about $(59.50 \%)$ of the total sample, and (81) female student representing (40.50\%). As shown in Table bachelor's degree from males and females stood at (126) students, and graduate were (74) students and the following figure illustrates this:

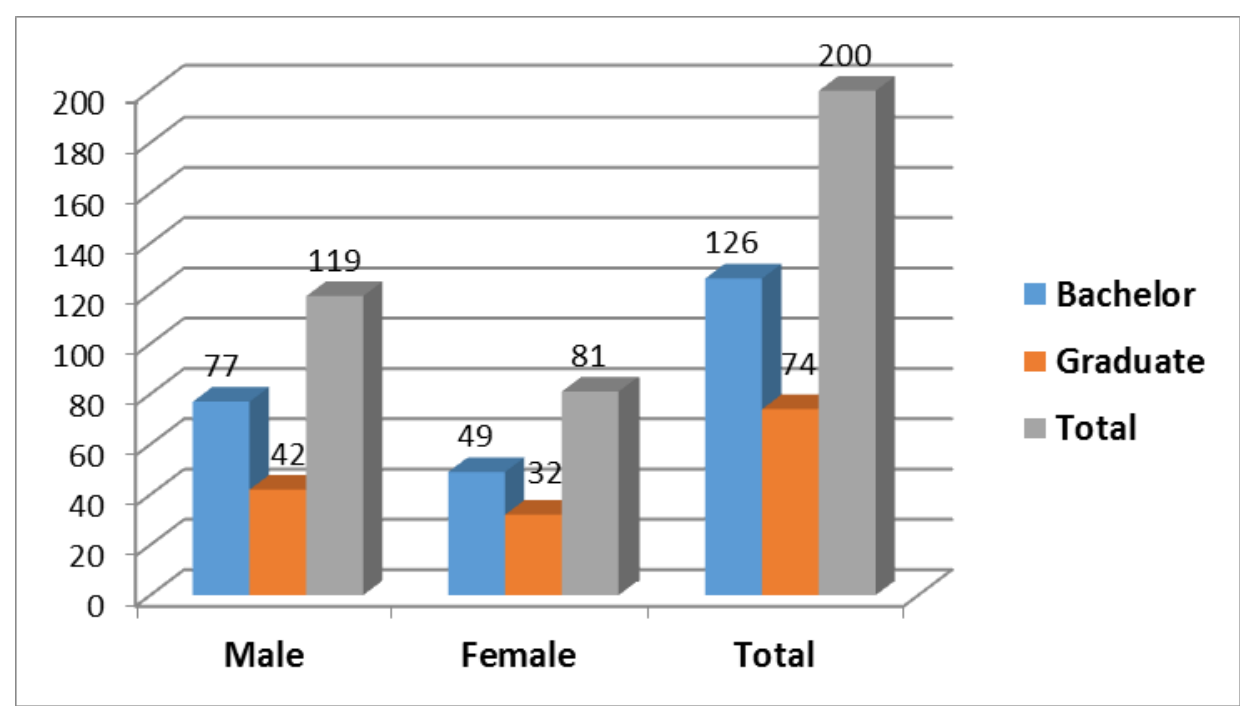

Figure 1. Sample's distribution according to the study variables of gender and Educational Qualification

\subsection{Tools of the Study}

To achieve the objectives of the study, the researcher developed a questionnaire in order to identify the patterns of media consumption of the Arab Spring from the viewpoint of Yarmouk University students. The researcher went to take the students' opinion on these reflections, where the questionnaire consisted of two sections: the first section was devoted to the introduction through which the researcher clarified the purpose of the study and its variables, while the second section was devoted to the items of questionnaire. 


\subsection{The Questionnaire Validity}

\subsubsection{Face Validity}

The questionnaire in its initial copy was presented on (10) arbitrators specialists arbitrators in the media college, in order to get to know the following: - the clarity of items, their importance, and the appropriateness on the response scale; as well as adding what they see fit and was not mentioned in the questionnaire. The percentage of $(80 \%)$ was identified as a minimum criterion of agreement among the arbitrators for judging the item validity. Depending on this criterion the final copy of the questionnaire consisted of (22) items which will reveal Yarmouk University students' responses towards the main dimensions of the media consumption of the Arab Spring.

\subsubsection{Internal Validity}

Questionnaire was distributed on a prospective sample of 47 of the Yarmouk University students; their responses were unloading in (SPSS 17) program. And then the correlation coefficient was identified. The following table illustrates more:

Tale 2. Pearson's Correlation coefficients of the questionnaire

\begin{tabular}{|c|c|c|}
\hline Questionnaire & correlation coefficient & Significance Value \\
\hline $\begin{array}{l}\text { The political dimension } \\
\text { The military dimension }\end{array}$ & & 0 \\
\hline $\begin{array}{l}\text { The military dimension } \\
\text { The humanitarian dimension }\end{array}$ & $0.801^{* *}$ & 0.000 \\
\hline
\end{tabular}

It can be noted from Table 2 that the total correlation coefficient of the questionnaire was $(0.801)$ which is a high correlation coefficient, as it is statistically significant at the level of significance $(0.000)$, and this shows that the questionnaire has an internal validity.

\subsection{Reliability of the Questionnaire}

\subsubsection{Cronbach's Alpha}

It is a method that requires calculating the value of correlation among the items (Michael, 2006). The following table shows the coefficients of reliability of the questionnaire using Cronbach's Alpha equation:

Table 3. Cronbach's Alpha

$\begin{array}{rr}\text { The Questionnaire } & \text { Cronbach's Alpha coefficient } \\ \text { The political dimension } & 0.875 \\ \text { The military dimension } & 0.763 \\ \text { The humanitarian dimension } & 0.710 \\ \text { The reliability of the Questionnaire } & 0.906\end{array}$

It can be seen from Table (3) that Cronbach's alpha coefficients for the patterns of media consumption on the Arab Spring were $(0.875,0.763,0.710)$, which are high reliability stability coefficients. It is also clear that the overall reliability coefficient was $(0.906)$, which is a high reliability coefficient.

\subsubsection{Correction Tool Method}

The questionnaire in its final form, after verifying the validity and reliability, consisted of (22) items, listed all of them on Likert's scale: (strongly agree, agree, neutral, oppose, strongly oppose) given the following grades respectively: (5.4, 3, 2.1). A judgment of evaluation was given to the extent of the effectiveness of the items through the adoption of arithmetic averages for each item in the questionnaire, according to the following correction key by calculating the length of the category in accordance with the following equation: [length = range / the number of categories] (Salmah, 2002).

Table 4. The questionnaire correction key in its final form

\begin{tabular}{|c|c|c|c|c|c|c|c|}
\hline \multicolumn{8}{|c|}{ degree of acceptance } \\
\hline $\begin{array}{l}\text { Strongly } \\
\text { Agree }\end{array}$ & Agree & Neutral & Oppose & $\begin{array}{l}\text { Strongly } \\
\text { Oppose }\end{array}$ & $\begin{array}{l}\text { Ihe high } \\
\text { degree }\end{array}$ & $\begin{array}{l}\text { The low } \\
\text { degree }\end{array}$ & The Variable \\
\hline $4.2-5$ & $\begin{array}{l}3.4 \text { and less } \\
\text { than } 4.2\end{array}$ & $\begin{array}{l}2.6 \text { and less } \\
\text { than } 3.4\end{array}$ & $\begin{array}{l}1.8 \text { and less } \\
\text { than } 2.6\end{array}$ & $\begin{array}{l}1 \text { and less than } \\
1.8\end{array}$ & 5 & 1 & $\begin{array}{l}\text { The Item } \\
\text { Average }\end{array}$ \\
\hline
\end{tabular}




\subsubsection{Statistical Methods}

Researcher depended in the analysis of results mainly on the computer using the Statistical Package for Social Sciences (SPSS) program version (17), the statistical methods used in this research to draw its results can be summarized in the following methods:

-Averages and standard deviations.

-T-test for independent samples Stondent (T-test) to check the differences between the averages in hypotheses.

\section{Discussion}

The researcher analyzed the results of his study in the light of the perceptions of a sample of students of the Faculty of Journalism at Yarmouk University, according to the following questions of the study:

The first question: What are the patterns of media consumption of the Arab Spring, in connection with the political dimension?

To answer this question the averages and standard deviations of the sample's responses for each item of the political dimension of media consumption patterns were calculated according to descending order, the following table shows that:

Table 5. Means and standard deviations and ranks of the students media colleges Responses regarding the political dimension

\begin{tabular}{|c|c|c|c|c|c|}
\hline No. & Item & Means & $\begin{array}{l}\text { standard } \\
\text { deviations }\end{array}$ & Rank & $\begin{array}{l}\text { The value of } \\
\text { influence }\end{array}$ \\
\hline 8 & $\begin{array}{l}\text { the Arab media raised the severity of some events during the Arab Spring in some } \\
\text { countries which had a negative impact. }\end{array}$ & 4.18 & 0.938 & 1 & high \\
\hline 3 & I want to watch political programs broadcast by the Arab media. & 4.05 & 1.000 & 2 & high \\
\hline 7 & $\begin{array}{l}\text { Financing channels is for the purpose of sabotage and dissemination of inaccurate } \\
\text { news. }\end{array}$ & 4.03 & 1.050 & 3 & high \\
\hline 6 & Al-Jazeera is considered to be neutral in the news that it broadcast. & 3.95 & 1.129 & 4 & high \\
\hline 1 & $\begin{array}{l}\text { Arab media are considered to be supportive of the principle of political } \\
\text { propaganda. }\end{array}$ & 3.92 & 0.976 & 5 & high \\
\hline 2 & The Arab media and through the talk shows stir sectarian strife. & 3.89 & 1.064 & 6 & high \\
\hline 4 & $\begin{array}{l}\text { The media is considered to be biased to some countries in transferring events at } \\
\text { the expense of other countries }\end{array}$ & 3.88 & 1.058 & 7 & high \\
\hline 5 & $\begin{array}{l}\text { Media is fully aware of how to stir the effects of political propaganda on } \\
\text { communities. }\end{array}$ & 3.74 & 1.004 & 8 & high \\
\hline Mean & & 3.96 & 0.178 & - & high \\
\hline
\end{tabular}

It is clear from table (5) that the item (8), which reads as follows: (the Arab media raised the severity of some events during the Arab Spring in some countries which had a negative impact.) has come first with a high effect by an arithmetic mean of (4.18), and standard deviation (0.938); this may be due to the fact that Arab media aired varied news from 82 different countries of the world in the main news bulletin (harvest of the day), The media also aired a total duration of 65 hours and 4 minutes and 27 seconds. The share of Tunisia was 1 minute, Egypt 7 minutes, Libya 1 minutes, Yemen 1 minute and Syria 3 minutes. So it is clear from the foregoing that the Arab media devoted a lot of time for most of the Arab Spring countries before the outbreak of revolutions. This is a clear indication that the media had a prominent role in the severity of the events during the Arab Spring. Item (5) has also a great effect and a mean of (3.74) and a standard deviation (1.004) and was ranked last, (Media is fully aware of how to stir the effects of political propaganda on communities.). This may be attributed to the fact that the media reflect a desire to bring about a change in the reality of the Arab Spring countries, which is for sure a wish to the contrary to the wishes of their political regimes. Nevertheless, the media did not leave any of these countries without a focus on human rights and democracy news in it. It is noticeable also that the media did not address the humanitarian and light threads at all, which means they do not want to minimize the importance of the political news and news of violence and terrorism one iota, despite the fact that simple repots of which confer on the bulletin a human dimension. The Arab Spring countries that received the most coverage ratio in most subjects in the media were Egypt, Syria, and Tunisia at least, this means that the channel is fully aware of stirring political propaganda in connection with the political side.

As it can be seen from the last table that all the items related to the political dimension came with a high impact with a mean of (3.96) and a standard deviation of (0.178).

Second question: What are the patterns of media consumption of the Arab Spring, in connection with the military dimension?

To answer this question the averages and standard deviations of the sample's responses for each item of the military dimension of media consumption patterns were calculated according to descending order, the following table shows that: 
Table 6. Means and standard deviations and ranks of the students Media colleges Responses regarding the military dimension

\begin{tabular}{|c|c|c|c|c|c|c|}
\hline $\begin{array}{r}\text { No } \\
.\end{array}$ & Item & Means & $\begin{array}{r}\text { standard } \\
\text { deviation } \\
\text { s }\end{array}$ & Rank & The & $\begin{array}{c}\text { value of } \\
\text { influence }\end{array}$ \\
\hline 10 & Arab media raised the severity of military events. & 3.98 & 1.054 & 1 & & high \\
\hline 9 & The media focus on the stereotype of the military war. & 3.92 & 1.075 & 2 & & high \\
\hline 11 & The media explain the military map with the help of experts & 3.91 & 1.031 & 3 & & high \\
\hline 13 & Media employ strategic experts for the appropriate use of media stereotype & 3.89 & 1.002 & 4 & & high \\
\hline 12 & $\begin{array}{l}\text { Media is considered to be supportive of some military factions through the } \\
\text { promotion for them. }\end{array}$ & 3.85 & 0.999 & 5 & & high \\
\hline 14 & The Arab media shed light on the nature of the battles on the ground & 3.77 & 1.083 & 6 & & high \\
\hline 15 & The media bias to some countries in the transfer of the events of the battles. & 3.74 & 1.046 & 7 & & high \\
\hline & Mean & 3.87 & 0.164 & - & & high \\
\hline
\end{tabular}

It is clear from table (6) that the item (10), which reads as follows: (Arab media raised the severity of military events.) has come first with a high effect by an arithmetic mean of (3.98), and standard deviation (1.054); this may be due to the fact that Arab media, including Aljazeera and Alarabya which had aired the battles live through their reporters on the grounds focusing on the stereotype of war through the help of strategic experts to explain the nature of areas in which the armed conflicts are taking place; all this backed up by photos and videos for some military battalions to raise the severity of fighting inside these areas. Item (15) was also with a high level of influence by a mean of (3.74) and a standard deviation of (1.046) ranked last (The media bias to some countries in the transfer of the events of the battles). This may be due to the fact that Media reflect the wish of their supportive countries in publishing the news that they see as appropriate for their political propaganda.

As it can be seen from the last table that all the items related to the military dimension came with a high impact with a mean of (3.96) and a standard deviation of (0.178).

Third question: What are the patterns of media consumption of the Arab Spring, in connection with the humanitarian dimension?

To answer this question means and standard deviations were calculated for the sample responses on each item of the humanitarian dimension according to the descending order as clarified in the following table:

Table 7. Means and standard deviations and ranks of the students Media colleges Responses regarding the humanitarian dimension

\begin{tabular}{|c|c|c|c|c|c|}
\hline No & Item & Means & $\begin{array}{r}\text { standard } \\
\text { deviations }\end{array}$ & $\begin{array}{ll}\text { Rank } & \text { The }\end{array}$ & $\begin{array}{l}\text { value of } \\
\text { influence }\end{array}$ \\
\hline 18 & $\begin{array}{l}\text { The media highlighting the humanitarian situation concerning the asylum and } \\
\text { relief cases. }\end{array}$ & 3.92 & 1.019 & 1 & high \\
\hline 20 & Media focus on refugee camps at certain times for $\mathrm{t}$ media consumption. & 3.87 & 1.009 & 2 & high \\
\hline 21 & Media allocate time for humanitarian crises & 3.83 & 1.324 & 3 & high \\
\hline 16 & Media employ activists in the refugee camps. & 3.80 & 1.838 & 4 & high \\
\hline 20 & Media is considered to be supportive of the refugee issues. & 3.78 & 0.629 & 5 & high \\
\hline 17 & The Arab media shed light on the humanitarian reality. & 3.73 & 1.285 & 6 & high \\
\hline 19 & Media focus on tragic humanitarian events in the areas of conflict. & 3.71 & 1.187 & 7 & high \\
\hline & Mean & 3.81 & 0.129 & - & high \\
\hline
\end{tabular}

It is clear from table 7 that the item (18), which reads as follows: (The media highlighting the humanitarian situation concerning the asylum and relief cases) has come first with a high effect by an arithmetic mean of (3.81) and standard deviation of (1.129); This is due to the crucial importance of this case in terms of securing the adequate shelter in coordination with the governments and international organizations such as the United Nations High Commissioner for Refugees (UNHCR); that is why there was a focus by media channels and social networking sites on this issue. . Item (19) was also with a high level of influence by a mean of (3.71) and a standard deviation of (1.187) ranked last (Media focus on tragic humanitarian events in the areas of conflict); through keeping in line with the situation of refugees on the relief and humanitarian level in general with the help of reporters inside the refugee camps and international organizations through periodic meetings with those in charge in these camps.

As it can be seen from the last table that all the items related to the humanitarian dimension came with a high impact with a mean of (3.81) and a standard deviation of (0.129).

Complementing the analysis of the results concerning the patterns of media consumption of the Arab Spring, means of the sample's responses on the dimensions of the study was extracted; the following table and figure illustrate those results. 
Table 8 . The means of the sample's responses towards the dimensions of the questionnaire

\begin{tabular}{rrr}
\hline The dimensions of media consumption patterns & Arithmetical mean & sample \\
political dimension & 3.96 & 3.87 \\
Military dimension & 3.81 & 200 \\
Human dimension & 3.87 \\
\hline
\end{tabular}

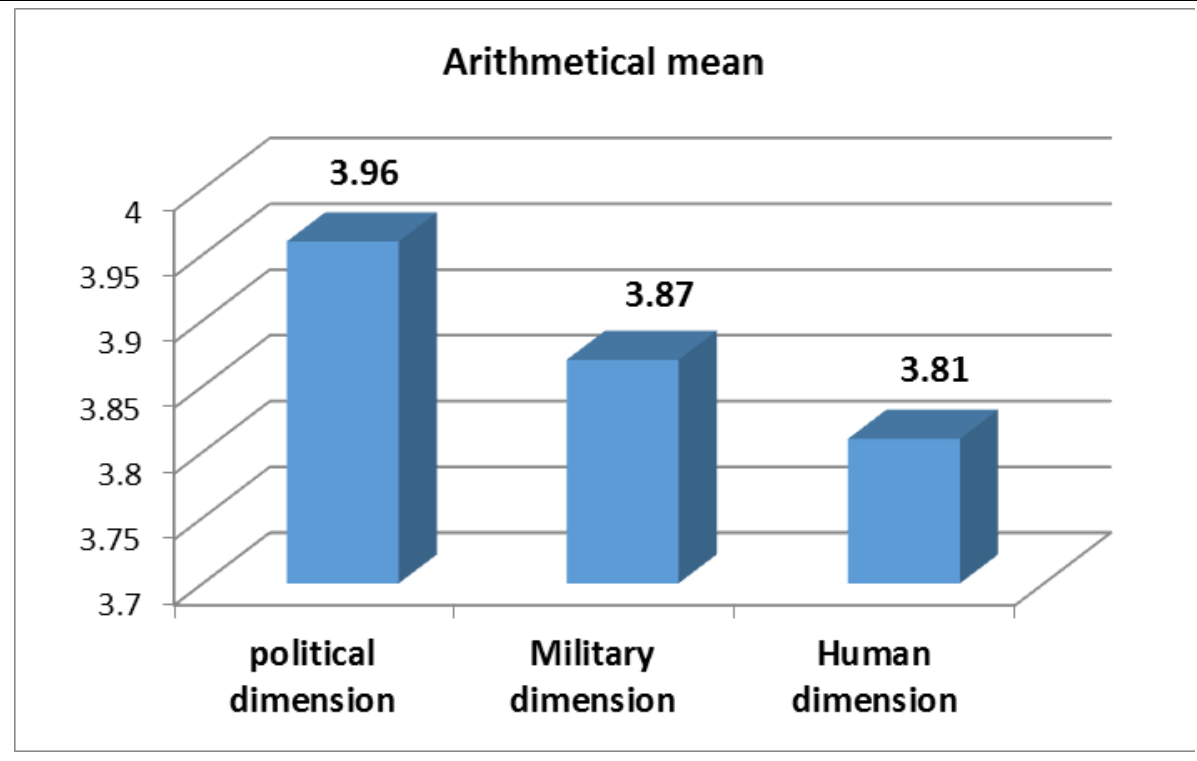

Figure 2. The dimensions of media consumption patterns

It is clear from table (8) and Figure (2) that the political dimension was with the highest mean of (3.96), followed by the military dimension, by a mean of (3.87) followed by the humanitarian dimension with a mean of (3.81).

The fourth question: Are there significant differences at the significance level $(\alpha=0.05)$ with respect to the views of respondents about patterns of media consumption of the Arab Spring attributed to the variable of gender?

To answer this question the null hypothesis which states that (there is no statistically significant differences at the level of the test $(\alpha=0.05)$ with respect to the views of respondents about patterns of media consumption of the Arab Spring due to the variable of gender) was tested using the ( $\mathrm{t}$-test) for two independent samples, as shown by the following table:

Table 9. T-test due to the variable of gender

\begin{tabular}{ccccccrr}
\hline The variable & Gender & No. & Mean & $\begin{array}{c}\text { Standard } \\
\text { Deviation }\end{array}$ & $\begin{array}{r}\text { The } \\
\text { value } \begin{array}{r}\text { of } \\
\mathrm{T}\end{array}\end{array}$ & $\begin{array}{r}\text { Freedom } \\
\text { degree }\end{array}$ & $\begin{array}{r}\text { The value of } \\
\text { influence }\end{array}$ Decision \\
$\begin{array}{c}\text { The general } \\
\text { Influence }\end{array}$ & Males & 119 & 122.85 & 24.687 & -1.17 & 198 & $0.242 \quad$ Not \\
significant
\end{tabular}

The results contained in Table (9) indicates that the value of (T) was (1.17-), which is not statistically significant at the level (0.05), where the values of significance were all greater than $(\alpha>0.05)$, and thus we accept the null hypothesis which states that ( there is no statistically significant differences at the level of the test $(\alpha=0.05)$ with respect to the views of respondents about patterns of media consumption of the Arab Spring due to the variable of gender). The reason for this is due to the fact that the students of the Faculty of Journalism at the University of Yarmouk, whether they are male or female, know the reality of the media as they are specialist followers, as well as they are well-informed of the curriculum on this subject during their school years.

The fifth question: Are there significant differences at the significance level $(\alpha=0.05)$ with respect to the views of respondents about patterns of media consumption of the Arab Spring attributed to the variable of educational qualification?

To answer this question the null hypothesis which states that (there is no statistically significant differences at the level of the test $(\alpha=0.05)$ with respect to the views of respondents about patterns of media consumption of the Arab Spring due to the variable of educational qualification) was tested using the ( $\mathrm{t}$-test) for two independent samples, as shown by the following table: 
Table 10. T-test due to the variable of educational qualification

\begin{tabular}{|c|c|c|c|c|c|c|c|c|c|}
\hline \multirow{3}{*}{ The } & The variable & Gender & No. & Mean & $\begin{array}{r}\text { Standard } \\
\text { Deviation }\end{array}$ & $\begin{array}{r}\text { The } \\
\text { value of } \\
T\end{array}$ & $\begin{array}{r}\text { Freedom } \\
\text { degree }\end{array}$ & $\begin{array}{l}\text { The value of } \\
\text { influence }\end{array}$ & Decision \\
\hline & patterns of & $\begin{array}{r}\text { Bachelor } \\
\text { degree }\end{array}$ & 126 & 27.28 & 24.7 .628 & \multirow{2}{*}{-0.67} & \multirow{2}{*}{198} & \multirow{2}{*}{0.529} & \multirow{2}{*}{$\begin{array}{r}\text { Not } \\
\text { significant }\end{array}$} \\
\hline & $\begin{array}{r}\text { media } \\
\text { consumption }\end{array}$ & $\begin{array}{r}\text { Graduate } \\
\text { studies }\end{array}$ & 74 & 25.68 & 6.221 & & & & \\
\hline
\end{tabular}

The results contained in Table (10) indicates that the value of (T) was (0.67-), which is not statistically significant at the level (0.05), where the values of significance were all greater than $(\alpha>0.05)$, and thus we accept the null hypothesis which states that ( there is no statistically significant differences at the level of the test $(\alpha=0.05)$ with respect to the views of respondents about patterns of media consumption of the Arab Spring due to the variable of educational qualification). The researcher attributes this result to the nature of thinking in judging the logical things, which are not contrary to logical thinking of the ongoing events in the Arab region and the world, in addition to that the students' experience helps them to be able to overcome the nature of mental problems imposed by the Arab reality due to the deepening of their specialty and the breadth of their knowledge of the reality of the Arab countries.

\section{Conclusion}

Nelson Mandela has said once "There is no easy walk to freedom anywhere, and many of us will have to pass through the valley of the shadow of death again and again before we reach the mountaintop of our desires".

The shadow of death in the Arab Spring revolutions is obviously represented by the terrorist groups that exploited the chaos in these countries to spread their ideologies and way of thinking which is nothing of Islam. And here from the mission of Media begins by first of all identifying the work mechanisms through which the media broadcast the political propaganda related to political, military and humanitarian dimensions and the methods used to do so. This should be done without violating the independence of the TV programs and to find the appropriate technical and administrative staff for those programs.

Regarding defending human values and rights, this must be a priority for all Arab satellite channels without prejudicing to any side, with spreading the true culture of tolerance and love regardless of the financial funder of these channels.

What has been mentioned above cannot be achieved without researching and the right scientific methods so studying the methods by which the advertising messages are broadcasted then analyzing and employing them for the public interest, side by side with analyzing the means by which the advertising messages are sent whether they were political or other, with the study of the methods used in the publication should be taken into account.

The media is the most powerful entity on earth. They have the power to make the innocent guilty and to make the guilty innocent, and that is power, because they control the minds of the masses. But the media can also put things in the right path if the will and most importantly the good people exist.

\section{References}

Abdul, G. H. (2011). How the state-owned media can be the restructured? The challenges of democratic transformation in Egypt during the transition phase, the Conference of the cooperation between the Cairo Institute for Human Rights Studies and the United Nations Fund for Democracy UNDEF and the Center for International Relations and external dialogue FRIDE, Spain, (Cairo: July 26 to 27, 2011)

Abdulrahman, E. (2016). Threat of the Downtrodden :The Framing Arab Refugees on CNN. Arab Media \& Society (Issue 21, Spring 2016).

Ala'alm, S. (2013). The media's role in democratic transition, Al Jazeera Centre for Studies.

Al-Abdullah, M. (2010). Arab satellite media's role in the "Arab revolutions", the Arab Association for Sciences of Communication, Lebanese University. 2010.

Al-Assaf, F. A. (2012). Advanced methods of management for international media advertising, magazine Baghdad College of Economic Sciences Journal, No. (29), the University of Baghdad: Baghdad.

Almana'ai, S. (2014). Arab Spring and the other face of the project the Middle East, the Middle East electronic Journal, source: http://aawsat.com/home/article/172761

Arabic Network for the Study of Democracy. (2013). Arab Spring revolution and the salvation from tyranny, Alshrouk for the book.

Besol, G. (2014). The prosperity of the Arab revolutions, source: http://www.bokra.net/Articles

Bouhnah, Q. (2012). Arab Media Message of Change: Implications and visions, the 17th International Conference of 
Philadelphia University, The culture of change: Dimensions and intellectual factors and representations (Kingdom of Jordan: 6-8 November, 2012.

Dulaimi, A. R. (2011). Introduction to Information and Communication Sciences, the House of Culture: Amman.

Gavrilos, D. (2002). Arab Americans in a nation's imagined community: How news constructed Arab American reactions to the Gulf War. Journal of Communication Inquiry, 26, 426-445. http://dx.doi.org/10.1177/019685902236900

Gholioun, B. (2015). Arab Spring revolutions between of the liberation of peoples and the nations' fall, the Arab electronic magazine, source: http://www.alaraby.co.uk/opinion

Ka'isis, K. (2012). Arab Spring between the revolution and the chaos, the University of Tizi Ouzou, Algeria.

Lauren, W. (2016). Islamic State Propaganda and the Main Stream Media. Law Institute for International policy. Sydney, Australia.

Mathieu, G. (2011). Le choc des révolutions arabes, Ed. Autrement, Coll. Frontières, Paris 2011.

Michael, A. (2006). Measurement and Evaluation in modern education. Fourth Edition, Damascus, Damascus University Press.

Mirghani, R. (2011). The role of media in the democratization of civil society -National Coalition for Media Freedom model, a working paper submitted to the program "Capacity building and the advancement of knowledge" to young Libyans journalists: Cairo of 15/21 July 2011.

Salha, A. R. (2013). Arab Spring where to, International Journal of fact, from the source: http://www.factjo.com/pages/print2.aspx?id=6131

Salmah, A. H. (2002). Statistics in Education. Amman: Scientific Yazouri House for publication and distribution.

Spooner, K. (2000). Strategies for Implementing Management Role of human resources Management. Journal of knowledge Management, 4(4).

This work is licensed under a Creative Commons Attribution 3.0 License. 